\title{
SINERGI DESA ADAT DAN PENGELOLA PARIWISATA DALAM PENGEMBANGAN PARIWISATA DI DESA WISATA PENGLIPURAN BANGLI
}

Kadek Sidhi Surya Libhi a, 1, I Gst. Agung Oka Mahagangga a, 2

${ }^{1}$ kadeksidhisuryalibhi@gmail.com, 2 ragalanka@gmail.com

a Program Studi S1 Destinasi Pariwisata,Fakultas Pariwisata,Universitas Udayana, Jl. Dr. R. Goris, Denpasar, Bali 80232 Indonesia

\section{ABSTRACT}

This research is located at a Tourism Village Penglipuran, Bangli aims to determine the existing condition and synergy Desa Adat and Pengelola Pariwista Penglipuran in the development of tourism in Penglipuran Tourism Village, Bangli.

Data collection techniques in this research are by observation, in-depth interviews, and study of the documentation relating to the secondary data in the field. The data have been obtained were analyzed by qualitative data analysis techniques that work with the data, organizing data, sorting them into manageable units, search and find patterns, find what is important, and what is learned, and deciding what can be describe to people other.

Results of this study were concluded that the existing condition of Tourism Village Penglipuran includes, physical and non-physical condition. Synergies Desa Adat and Pengelola Pariwisata Penglipuran in the development of tourism at the Tourism Village Penglipuran is customary village as a tourism asset owners served as a maker and designer of the policy, while the tourism manager in charge of implementing the tourism policy. Moreover, in the management of the tourism activity undertaken by Pengelola Pariwisata, Desa Adat authorities to supervise all activities of tourism at the Tourism Village Penglipuran.

Keywords: Synergy, Desa Adat, Pengelola Pariwisata, Tourism Development, Tourism Village

\section{PENDAHULUAN}

Bali merupakan destinasi unggulan di Indonesia yang memiliki banyak potensi, berupa keindahan alam. Keindahan alam pulau Bali ini dibuktikan dengan banyak nya atraksi wisata berbasis alam yang ada di Bali, dan biasa nya atraksi yang berbasis alam ini dibarengi dengan keunikan dari kebudayaan masyarakat lokal di daerah tersebut. Modal yang kuat tersebut, pemerintah membuat program Desa Wisata yang dimaksudkan untuk mengembangkan dan mengelola potensi pariwisata yang ada di sebuah desa dengan memberdayakan masyarakat lokal. Keuntungan dari program Desa Wisata ini, bukan hanya dalam melestarikan atraksi maupun budaya masyarakat lokal, juga masyarakat lokal mendapat manfaat ekonomi dari adanya pariwisata ini.

Desa Wisata di Bali yang menjadi tujuan utama wisatawan adalah Desa Wisata Penglipuran, Bangli. Desa Wisata Penglipuran dalam pengelolaan potensi pariwisata tentu memiliki badan pengelola yang dalam hal ini disebut Pengelola Pariwisata Penglipuran yang berada dibawah naungan desa adat Penglipuran. Desa adat inilah yang memiliki tugas dan wewenang untuk mengatur dan mengurus urusan pemerintahan, yang sekaligus juga berwenang untuk mengatur dan mengurus masyarakat desa. Di Bali, secara umum sistem pemerintahan desa yang dianut adalah desa dinas yang dikepalai oleh Perbekel atau Kepala Desa dan desa adat yang dikepalai oleh Bendesa Adat. Desa dinas bertugas dan berwenang dalam urusan administratif, sedangkan desa adat bertugas dan berwenang dalam urusan adat, termasuk didalam nya menyangkut didalam nya tradisi dan awig-awig (peraturan adat masyarakat desa).

Tetapi khusus di Desa Penglipuran, sistem pemerintahan desa yang dianut adalah sistem tunggal, dimana desa adat yang memegang penuh sistem pemerintahan desa, segala sesuatunya berpedoman kepada awigawig (peraturan adat Desa Penglipuran) sehingga pihak lain tidak dapat mengintervensi desa adat.

Selama ini, desa adat dan pengelola pariwisata Penglipuran sudah menjalankan perannya masing-masing dengan baik, tetapi sangat dimungkinkan terjadi kesalahpahaman dalam proses pengelolaan pariwisata di Desa Wisata Penglipuran, karena menurut Bendesa adat Desa Penglipuran, desa adat dan pengelola pariwisata Penglipuran memiliki tugas dan wewenang untuk mengelola kegiatan pariwisata di Desa Penglipuran. Sehingga untuk mengetahui tugas dan wewenang desa adat dan pengelola pariwisata Penglipuran, serta 
kemungkinan terjadi kesalahpahaman dalam menjalankan tugas dan wewenang tersebut, maka menarik dilakukan penelitian tentang kondisi eksisting Desa Wisata Penglipuran dan sinergi desa adat dan pengelola pariwisata Penglipuran dalam pengembangan pariwisata di Desa Wisata Penglipuran, Bangli.

\section{KEPUSTAKAAN}

\subsection{Telaah Hasil Penelitian Sebelumnya}

Tinjauan penelitian sebelumnya yang dijadikan referensi adalah jurnal "Peranan Desa Adat Sangeh dalam Pengelolaan Daya Tarik Wisata Sangeh, Kabupaten Badung" oleh Agus Muriawan Putra (2013) dan jurnal "Dampak Perkembangan Pariwisata di Objek Wisata Penglipuran" oleh Putu Agus Prayogi (2011).

\subsection{Deskripsi Konsep dan Teori}

Deskripsi konsep yang terdapat dalam jurnal ini meliputi konsep sinergi (Walton dalam Sulasmi, 2009), konsep desa adat (Undang Undang No 6 Tahun 2014 tentang Desa), konsep pengembangan pariwisata (Prayogi, 2011), dan konsep Desa Wisata (Muriawan, 2006), Teori Struktural fungsional, dan teori Partisipasi (Arnstein dalam Arida, 2014).

\section{METODOLOGI PENELITIAN}

Lokasi penelitian ini dilaksanakan di Desa Wisata Penglipuran, Kecamatan Kubu, Kabupaten Bangli, Bali

Ruang lingkup penelitian ini yang adalah kondisi eksisting Desa Wisata Penglipuran, meliputi kondisi fisik dan kondisi non-fisik desa wisata Penglipuran, serta sinergi desa adat dan pengelola pariwisata dalam pengembangan pariwisata di Desa Wisata Penglipuran.

Jenis dan sumber data dalam penelitian ini adalah jenis data kualitatif. Sumber data dalam penelitian menurut Sugiyono (2014) meliputi data primer data sekunder.

Teknik pengumpulan data yang digunakan dalam penelitian ini adalah teknik Observasi (pengamatan), Dept Interview (wawancara mendalam), dan Studi Dokumentasi Teknik penentuan informan dalam penelitian ini adalah teknik purposive sampling, (Sugiyono, 2014).

Teknik analisis data yang digunakan dalam laporan penelitian ini adalah teknik analisis data kualitatif (Bogdan dan Biklen dalam Moleong, 2012). merupakan upaya yang dilakukan dengan jalan bekerja dengan data, mengorganisasikan data, memilah-milahnya menjadi satuan yang dapat dikelola, mencari dan menemukan pola, menemukan apa yang penting, dan apa yang dipelajari, dan memutuskan apa yang dapat diceritakan kepada orang lain.

\section{HASIL DAN PEMBAHASAN \\ 4.1 Kondisi Eksisting Desa Wisata Penglipuran}

\subsubsection{Kondisi Fisik Desa Penglipuran}

Secara administrasi Desa Wisata Penglipuran memiliki luas wilayah 112 ha dengan batas-batas wilayah administrasi sebelah Utara Desa Adat Kayang, Timur Desa Adat Kubu, Barat Desa Adat Cekeng, dan Selatan Desa Adat Cempaga.

Kondisi fisik desa Penglipuran dapat dibagi menjadi penggunaan wilayah dan infrastrukur yang terdapat di Desa Penglipuran. Penggunaan wilayah Desa Wisata Penglipuran didominasi untuk lahan pertanian dengan luas $50 \mathrm{Ha}$, kawasan hutan bambu seluas $45 \mathrm{Ha}$, Kemudian ada pemukiman yang terletak di tengah wilayah Desa Wisata penglipuran seluas 9 Ha yang terdiri dari 76 pekarangan. Terdapat pula tempat suci dengan luas $4 \mathrm{Ha}$ Dan terakhir ada fasilitas umum yang meliputi, Balai Banjar, toilet umum dan Bale Bengong (Rest Area).

Sarana dan prasarana yang terdapat di Desa Wisata Penglipuran yaitu, tempat pertemuan diantaranya, Balai Banjar 2 buah, Gedung Paku Çura Yudha 1 buah, Balai Patok, 1 buah, Tempat parkir dengan luas total 65 are.

4.1.2 Kondisi Non-fisik Desa Penglipuran

Kondisi non-fisik desa Penglipuran ini menyangkut segala sesuatu yang tidak dapat dirasakan oleh panca indra. Kelembagaan adalah kondisi non-fisik yang pertama, kelembagaan yang ada di Desa Wisata Penglipuran dapat dibagi 3 (tiga), yaitu Lembaga Adat (Desa Adat Penglipuran) diantaranya lembaga Desa Adat dan lembaga adat yang berada dibawah naungan desa adat, Lembaga Dinas diantaranya Lingkungan Penglipuran/Banjar Dinas Penglipuran, Pemberdayaan Kesejahteraan Keluarga (PKK), Hansip, dan Posyandu, dan Lembaga pendukung baik adat maupun kedinasan, diantaranya Kelompok Wanita Tani (KWT), Kelompok Perajin, Kelompok Ternak Sekaa Santi dan Sanggar Seni Tari dan Tabuh. 
Pemerintahan Desa Adat Penglipuran dipimpin oleh seorang Bendesa Adat dibantu oleh 2 orang Penyarikan, 12 orang Kancan Roras, Kelian Sekaa Gong, Kelian Sekaa Baris, Kelian Sekaa teruna, Kelian Pecalang, Pengurus Pengelola Pariwisata, dan Pengurus (LPD).

Jumlah KK (Kepala Keluarga) di desa Penglipuran 233 jiwa, dengan total jumlah penduduk keseluruhan 936 jiwa yang dibagi menjadi penduduk laki-laki 469 jiwa dan perempuan 467 jiwa.

\subsection{Sinergi Desa Adat dan Pengelola Pariwisata Penglipuran dalam Pengembangan Pariwisata di Desa Wisata Penglipuran}

\subsubsection{Peran Desa Adat}

Desa Wisata Penglipuran sebagai daya tarik wisata yang berbasis masyarakat tentu akan memaksimalkan peran masyarakat lokal untuk ikut serta dalam segala kegiatan yang dibuat oleh desa Penglipuran. Peran masyarakat tersebut dalam hal pemerintahan desa, pengelelolaan pariwisata dan pengelolaan harta kekayaan desa nya. Masyarakat lokal juga bertugas sebagai pengawas dan pemberi masukan terhadap pemerintahan desa.

Sistem pemerintahan Desa Wisata Penglipuran sedikit berbeda dengan sistem pemerintahan desa di Bali secara umum. Di Desa Wisata Penglipuran meggunakan sistem Bendesa Adat, bukan sistem Kepala Desa. Untuk di desa-desa lain yang ada di Bali biasanya menggunakan sistem pemerintahan desa ganda, dimana terdapat desa dinas dan desa adat. Desa dinas bertugas dan berwenang dalam bidang administrasi, dan dikepalai oleh seorang Kepala Desa / Perbekel. Sedangkan desa adat bertugas dan berwenang dalam bidang adat, yang di dalamnya termasuk adat-istiadat dan awig-awig (peraturan adat). Desa adat ini dikepalai oleh seorang Bendesa. Desa adat nantinya akan bertanggung jawab kepada Kepala Desa / Perbekel. Di Desa Wisata Penglipuran, Bendesa adat juga bertugas seperti Kepala desa / Perbekel sehingga pertanggungjwaban nya langsung ke Pemerintah Daerah. Desa adat yang berperan mengelola desa secara mandiri, tanpa ada campur tangan dari pihak luar (Kelurahan Kubu) walaupun secara administratif kewilayahan, desa Penglipuran masuk ke dalam wilayah Kelurahan Kubu, Bangli. Dalam bidang administrasi langsung ditangani oleh desa adat dan langsung berhubungan dengan Pemkab Bangli tanpa melaui kelurahan Kubu. Hubungan ke kelurahan Kubu hanya sebatas dalam pengurusan KTP (Kartu Tanda Penduduk) dan KK (Kartu Keluarga) melalui Kepala Lingkungan Penglipuran.

Secara umum, desa adat bertugas mengayomi masyarakatnya, membuat aturanaturan desa (awig-awig), mengelola harta kekayaan desa (baik fisik maupun non fisik), bersama pemerintah daerah ikut menentukan pembangunan desanya di segala bidang, khususnya di bidang agama, budaya, dan kemasyarakatan, dan desa adat juga berwenang untuk melakukan peradilan adat untuk masalahmasalah yang tidak dapat diselesaikan secara kekeluargaan atau musyawarah. Dengan kata lain, desa adat yang melaksanakan pemerintahan desa tanpa ada intervensi baik oleh pihak lain, walaupun masih berkoordinasi dengan pemerintah daerah dalam hal pembangunan berkelanjutan desa. Desa adat memiliki kekuasaan penuh untuk mengelola kegiatan kemasyarakatan desa secara umum, namun tetap dengan persetujuan masyarakat desa, karena yang masuk ke dalam anggota desa adat adalah seluruh masyarakat Desa Penglipuran.

Dalam bidang kepariwisataan, desa adat memegang wewenang penuh karena aset seluruhnya adalah milik desa, dan pemerintah hanya sebatas memberikan pembinaan. Karena kepariwisataan merupakan salah satu aset kekayaan desa, desa adat memiliki tanggung jawab untuk mengelola pariwisata dengan sebaik-baiknya dan memberikan manfaat positif kepada masyarakat desa Penglipuran.

Secara tidak langsung yang termasuk dalam desa adat ini juga merupakan warga desa Penglipuran. Dalam pelaksaannya, semua sekaa atau kelompok masyarakat, sekaligus juga warga Penglipuran dibawah Bendesa adat ini berperan sebagai daya tarik tambahan yang membuat wisatawan semakin tertarik datang ke Desa Wisata Penglipuran. Jika dalam proses kegiatan wisata terjadi permasalahan antar bagian atau dalam satu bagian di struktur tersebut, maka diselesaikan secara musyawarah dalam forum desa adat dan hasilnya akan disampaikan langsung oleh Bendesa adat kepada seluruh warga Desa Penglipuran. 


\subsubsection{Peran Pengelola Pariwisata Penglipuran}

Pengelola pariwisata Penglipuran merupakan suatu badan yang berada dibawah naungan desa adat yang bertugas untuk mengelola pariwisata di Desa Wisata Penglipuran. Pengelola pariwisata Penglipuran ini ini dibentuk tahun 2012 atas dasar kepariwisataan yang membutuhkan tenaga profesional untuk mengelola pengembangan pariwisata desa Penglipuran. Selain itu, pengelola pariwisata Penglipuran ini dibentuk karena tugas dan wewenang desa adat sebagai pemilik aset pariwisata yang memiliki tugas dan wewenang sangat kompleks sehingga perlu dibentuk badan pengelola yang bersifat mandiri dan kompeten agar masyarakat desa Penglipuran mendapat manfaat yang positif akibat kegiatan pariwisata ini. Pengelola pariwisata ini juga sebagai bentuk perpanjangan tangan desa adat dalam kegiatan kepariwisata di Penglipuran sehingga setiap kegiatan yang dilaksanakan pengelola pariwisata ini harus mendapat persetujuan dari desa adat. Evaluasi kegiatan pariwisata di desa Penglipuran dilakukan oleh Pengelola Pariwisata Penglipuran setiap bulan dan hasilnya akan dilaporkan pada forum musyawarah desa adat sebagai bentuk pertanggung jawaban pengelola terhadap desa adat.

Perekrutan karyawan pengelola pariwisata Penglipuran dilakukan oleh desa adat melalui forum musyawarah desa adat. Karyawan yang bekerja sebagai pengelola pariwisata dipilih dari masyarakat desa Penglipuran sesuai kompetensi yang dimiliki dan kemudian diajukan pada forum musyawarah tersebut. Hal ini menandakan sistem yang digunakan cenderung tradisional karena tidak ada syarat yang pasti seperti dalam perekrutan karyawan dalam perusahaan besar, tetapi sistem tradisional ini yang juga membuat kinerja karyawan baik. Disamping karena sudah mengenal satu sama lain, karyawan juga lebih mudah beradaptasi dengan karyawan lain. Untuk pemberhentian karyawan juga dilakukan dalam forum musyawarah desa adat. Sistem perekrutan dan pemberhentian karyawan ini dilakukan dalam sistem kekeluargaan, yang lebih menekankan pada komunikasi dan musyawarah mufakat. Untuk sistem gaji, gaji hanya diberikan kepada karyawan yang bertugas sehari-hari, seperti salah satunya bagian tiket, sedangkan manajer, wakil manajer, admin kordinator, kordinator operasional dan kordinator pengembangan tidak mendapatkan gaji, hanya mendapat biaya operasional setiap ada kegiatan, seperti : rapat.

Peran yang dimiliki pengelola pariwisata Penglipuran ini sangat kompleks karena pengelola pariwisata ini yang mengelola setiap aspek dalam kepariwisataan. Pengelola pariwisata Penglipuran sebagai lembaga khusus yang menanagani kepariwisataan di Desa Wisata Penglipuran bertugas untuk mengelola pariwisata Penglipuran baik dari segi operasional maupun pengembangan, yang meliputi perencanaan, pelaksanaan, evaluasi dan pelaporan / pertanggung jawaban. Dalam aspek perencanaan pariwisata, setiap kegiatan yaang dirancang akan terlebih dahulu diajukan ke desa adat untuk disetujui, karena secara struktur organisasi, pengelola pariwisata ini berada dibawah naungan desa adat dan setelah disetujui kemudian dilaksanakan oleh pengelola pariwisata Penglipuran. Dalam aspek operasionalnya, pengelola pariwisata Penglipuran melakukan pemungutan retribusi tiket masuk dari wisatawan yang berkunjung, hasil dari tiket masuk tersebut $60 \%$ masuk ke pemerintah daerah, 20\% masuk ke kas desa adat, dan 20\% untuk operasional kegiatan pariwisata di Penglipuran. Setiap kegiatan pariwisata akan dievaluasi dan dilaporkan kepada desa adat setiap bulan.

\subsubsection{Sinergi Desa Adat dan Pengelola Pariwisata Penglipuran}

Dalam pengembangan pariwisata di Desa Wisata Penglipuran, desa adat tidak bisa mengelola sendiri pariwisata di Penglipuran sehingga memberikan wewenang penuh terhadap pengelola pariwisata Penglipuran. Dalam melaksanakan tugas dan wewenang nya pengelola pariwisata Penglipuran melaksanakan nya secara mandiri dan independent tanpa ada intervensi dari pihak luar. Setiap kegiatan yang dilakukan maupun direncanakan oleh pengelola pariwisata Penglipuran harus diketahui disetujui oleh desa adat dan kemudian disampaikan oleh Bendesa adat ke seluruh warga desa Penglipuran.

Walaupun desa adat telah menyerahkan sepenuhnya kegiatan pariwisata dikelola oleh pengelola pariwisata Penglipuran, namun desa 
adat tetap memiliki tugas dan wewenang untuk mengawasi setiap kegiatan pariwisata di Penglipuran dan juga mengawasi kinerja dari pengelola pariwisata Penglipuran. Dalam hal pengelolaan kepariwisataan di Desa Wisata Penglipuran, pengelola pariwisata Penglipuran melaksanakan segala kebijakan yang telah dibuat dan disetujui dalam forum musyawarah desa adat, sekaligus didalam nya juga ada aspek pengelolaan kepariwisataan di Desa Wisata Penglipuran. Desa adat bertugas dan berwenang untuk mengawasi segala yang berkaitan dengan kepariwisataan, termasuk juga jika terjadi permasalahan yang tidak dapat diselesaikan oleh pengelola pariwisata, maka desa adat yang menyelesaikan permasalahan tersebut.

Secara struktur organisasi juga pengelola pariwisata berada di bawah desa adat, sehingga apapun permasalahan yang terjadi dalam pengelolaan pariwisata akan diselesaikan dulu oleh pengelola pariwisata, jika tidak bisa diselesaikan oleh pengelola akan diselesaikan oleh desa adat. Dalam pengembangan pariwisata di Penglipuran, desa adat juga membuat kebijakan dalam bidang pariwisata, dengan mekanisme desa adat dan juga pengelola pariwisata Penglipuran menyusun rancangan nya, kemudian diajukan ke forum musyawarah desa adat, ketika kebijakan tersebut disetujui dan diputuskan maka sebagai pelaksananya adalah pengelola pariwisata Penglipuran.

$$
\text { Yang terpenting dalam sistem }
$$

kemasyarakatan Desa Wisata Penglipuran adalah walaupun desa adat memiliki aset desa secara umum, tetapi yang menjadi anggota desa adat itu sendiri adalah masyarakat desa Penglipuran secara keseluruhan. Jadi dapat dikatakan jika masyarakat lokal yang memiliki aset desa secara umum maupun dalam bidang kepariwisataan. Masyarakat lokal juga yang secara tidak langsung mengelola aset desa yang dimiliki. Pengelola pariwisata sebagai bagian dari desa adat juga berasal dari masyarakat lokal desa Penglipuran yang memiliki keahlian dalam bidang pariwisata untuk mengelola kepariwisataan. Dalam hal ini, masyarakat lokal secara keseluruhan yang berpartisipasi untuk mengembangkan pariwisata di Desa Wisata Penglipuran.

\section{SIMPULAN DAN SARAN \\ 5.1 Simpulan}

Berdasarkan penelitian ini dapat disimpulkan bahwa kondisi eksisting dari Desa Wisata Penglipuran meliputi, kondisi fisik dan kondisi non-fisik. Kondisi fisik yang unik dari Desa Wisata Penglipuran ini adalah kesamaan angkul-angkul, terhubungnya satu rumah dengan yang lain. Kondisi non-fisik yang tidak ada ditempat lain adanya desa adat yang mengatur pemerintahan secara umum, dan dalam bidang pariwisata secara khusus.

Sinergi desa adat dan pengelola pariwisata Penglipuran dalam pengembangan pariwisata di Desa Wisata Penglipuran adalah desa adat sebagai pemilik aset pariwisata bertugas sebagai pembuat dan perancang kebijakan, sedangkan pengelola pariwisata bertugas melaksanakan kebijakan pariwisata tersebut dan desa adat berwenang untuk mengawasi segala kegiatan pariwisata di Desa Wisata Penglipuran.

\subsection{Saran}

Saran pertama kepada pengelola pariwisata Penglipuran agar lebih meningkatkan koordinasi dengan desa adat, serta meningkatkan kualitas Sumber Daya Manusia (SDM) Pariwisata untuk meningkatkan daya saing dalam rangka mengatisipasi perkembangan dan permasalahan yang semakin komplek dibidang kepariwisataan.

Saran selanjutnya untuk desa adat agar lebih mengawasi kegiatan pariwisata di Desa Wisata Penglipuran agar tetap dapat menarik wisatawan untuk berkunjung ke desa Penglipuran dan dapat memberikan dampak positif ke seluruh masyarakat desa Penglipuran.

\section{DAFTAR PUSTAKA}

Anonim. Undang Undang No 6 Tahun 2014 tentang Desa.

Anonim. Undang Undang No 10 Tahun 2009 tentang Kepariwisataan.

Arida, I Nyoman Sukma. 2014. Disertasi "Dinamika Ekowisata Tri Ning Tri di Bali (Proses Perkembangan Produk, Pelibatan Masyarakat, dan Strategi Pengembangan)". Yogyakarta (tidak dipublikasikan).

Gunawan, Imam. 2013. Metode penelitian Kualitatif, Teori \& Praktik. Jakarta: Bumi Aksara.

Prayogi, Putu Agus. 2011. Dampak Perkembangan Pariwisata Di Objek Wisata Penglipuran. Jurnal Perhotelan dan Pariwisata, Vol. 1 No. 1, STIPAR Triatma Jaya.

Putra, Agus Muriawan. 2013. Peranan Desa Adat Sangeh dalam Pengelolaan Daya Tarik Wisata Sangeh, 
Vol. 4 No 2, 2016

Kabupaten Badung. Jurnal Perhotelan dan Pariwisata, Vol.3 No.1, STIPAR Triatma Jaya.

Moleong, Lexy J. 2012. Metode Penelitian Kualitatif. Bandung: PT Remaja Rosdakarya.

Pitana, I Gde dan Putu G Gayatri. 2005. Sosiologi Pariwisata. Yogyakarta: Andi

Sugiyono. 2014. Metode Penelitian Kuantitatif, Kualitatif, dan $R \& D$. Bandung : Alfabeta. 